The UK Netball Superleague: A Case Study of Franchising in Elite Women's Sport

Dr. Louise Mansfield, Deputy Director BC.SHaW,

Brunel University, School of Sport and Education, Kingston Lane, Uxbridge, Middlesex. UK. UXB 8PH

Tel: +44 (0) $1895267561 \quad$ Email: louise.mansfield@ brunel.ac.uk

Dr. Lara Killick, Assistant Professor (Sociology of Sport and Sport Pedagogy)

University of the Pacific, Department of Health, Exercise and Sport Science, 3601 Pacific Avenue, Stockton, CA. 95211.

Tel: (209) 9462981 Email: Ikillick@ pacific.edu 


\title{
The UK Netball Superleague: A Case Study of Franchising in Elite Women's Sport
}

\begin{abstract}
This paper draws on theories of franchising in examining the emergence of the UK Netball Superleague in 2005. The focus of the paper is to explore the development of an empowered franchise framework as part of England Netball's elite performance strategy and the consequences of the Superleague for player performance, team success, and commercial potential of the franchises. The findings from 22 in-depth interviews conducted between 2008-2011 with franchise personnel and sport media/marketing consultants inform the discussion. The paper further comments on the implications of the empowered franchise system for developing NGB elite performance strategies.
\end{abstract}

\section{Introduction}

Emerging in the late $19^{\text {th }}$ century as a sport "initially designed and traditionally administered as an activity for promoting appropriate forms of femininity" (Tagg, 2008, p 410), Netball is played by more than 20 million people in over 80 nations across the globe (INFA, 2011). It is an invasion ball game predominantly played by girls and women between teams of 7 players. Played with a round ball, netball takes place on both indoor and outdoor rectangular courts $(30.5 \mathrm{~m}$ long/15.25m wide) and the objective of the game is to pass the ball between players on the same team scoring goals in the opposing team's net.

There are several versions of the game, some aimed at developing netball skills and knowledge for children (see for example High 5 in England, UK), and some at developing faster and more exciting performances at elite level (see for example the Fastnet World series). The traditional form of the game, played in international tests, lasts 60 minutes and is separated into 15-minute quarters. Governed by International Federation Netball Association (IFNA), the regular international schedule consists of three major competitions, the quadrennial World Netball Championships, the Commonwealth Games and the annual World 
Netball Series. World rankings are determined on performances in Test matches played since July 2009 and at the time of press New Zealand are ranked $1^{\text {st }}$, Australia $2^{\text {nd }}$ and England $3^{\text {rd }}$ (IFNA 2012). In addition, annual transnational competitions in the form of the ANZ Championship (Australian and New Zealand teams) and the UK Netball Superleague (NSL) operate in their respective countries. The NSL, the top tier elite competition in UK netball, is played annually between January and May. It combines elite UK players and international athletes playing currently in 8 franchise teams from England and Wales.

This paper examines the emergence of the NSL in 2005 and the subsequent development of an empowered franchise model. The paper is divided into 8 main sections. It begins with an overview of elite performance strategies for sport in the UK noting the political context in which the NSL was developed. It then discusses the strategic planning processes underpinning the emergence of the NSL. We provide a brief overview of franchising in sport before examining the organisation and structure of the empowered franchise model in the NSL. The paper discusses the role of intrapreneurs in the management of franchises and explores the commercial potential of a franchising approach. The final commentary focuses on the challenges faced by managers in the franchise system and the implications of our observations for managers and researchers in the sport management field.

\section{Performance Sport in the UK: Strategy, Governance and NGBs}

Developing a strategy is at the core of sport management and is likely to influence the success of sport organisations (Amis, et al., 2004; Nicholson \& Hoye, 2008). In the sense that strategy can be explained as the bridge between a sport organization and the environment in which it operates, a strategy involves decision making in relation to: the direction and scope of an organisation; resource capabilities; and stakeholder views (Hoye et al., 2008). Strategy involves planning, the activities that need to be undertaken to implement a strategy, while 
strategic management is the overlapping process of both strategy and planning activities (Minikin, 2012).

Strategy, planning and strategic management functions cannot be separated from the principles of good governance in relation to transparency, accountability, democracy, responsibility, equity, efficiency and effectiveness (Henry \&Lee, 2004). For example, as Mowbray (2012) argues, in achieving effective standards of planning, any board must allocate their efforts towards thinking strategically about a sport organization. Governance can be usefully thought of as a "means-ends relationship"; a set of processes that are concerned with "defining ends and controlling means to achieve ends" (Gammelsaeter, 2010,p 570). Strategy and planning, then, are a means by which a sports organisation can achieve a defined end. Governance and hence strategy are principally driven by context (Gammelsaeter, 2010).

Most recently, strategies for elite performance sport in the UK have been framed by political and financial concerns about the management of NGBs. In the UK sporting system, at least two decades of fragmented organisation and policy-making have led to a range of accusations of bad governance, complex and chaotic funding practices, lack of effective strategy and inadequate short-term initiatives (Dutton, 2009). Failures in the organisational and financial governance of UK sport organisations have led to modernisation reforms aimed at strategy, planning and strategic management in relation to resource-efficiency, outcomeeffectiveness and inclusive-progressive policy delivery (Birkbeck Sport Business Centre, 2010; Grix, 2009; Harrison, 2010; McDonald, 2005). The 2005/06 England Netball annual report alludes to organisational, strategic and governance changes stating that:

England Netball has recently undergone some major organisational and structural changes that have resulted in, among other things, staff and management changes, a competition review and a change to our infrastructure and corporate governance... we 
are in the 2nd year of our 4-year Whole Sport Plan, pursuant to which we receive funding from Sport England for the development of our sport. Under this plan, we will continue to focus on our 4 main strategic goals; Lifelong Participation and Competition, England Leading the World, Quality Systems and Networks and Performance as an Organisation. (England Netball, 2006, p 4).

The emergence of the NSL in 2005 occurred in the context of such on-going strategic and governance approaches within England Netball particularly in relation to the development of elite performance and national success. Since the 1980s, various Sport England strategies have set specific objectives and instigated reforms to create effective delivery structures for UK NGBs to increase participation and achieve success on an international scale (Sport England, 2004, 2008). Over the past 7 years, England Netball reforms have been far reaching and emphasise on-going modernisation in the areas of elite performance, talent development and mass participation. Since 2005, annual reports published by England Netball have emphasised the importance of elite performance strategies highlighting, for example, the importance of the National Coaching Framework for Young People to deliver an effective competition structure for long term athlete development (England Netball, 2007) and the appointment of a National Talent Manager to direct talent development (England Netball, 2008). Currently, netball is a Sport England priority sport for development based on the importance of the game in increasing participation amongst girls and women. This status represents a direct link between elite performance and the ability of the England Netball team to maintain a top five world ranking, and grass roots development. NGBs of priority sports are required to produce Whole Sport Plans to develop broad strategy on budgetary spending and produce and meet performance targets, including world rankings expectations (Sport England, 2008). 
In England Netball's Whole Sport Plan for 2005-09 a strategy for investment in high performance netball and talent development was identified within an objective for "Nurturing Talent and Developing Excellence" at a proposed investment (from a Sport England grant) valued at $£ 1,315,762$ (England Netball, 2005, p.7). Part of this investment was to "introduce an enhanced elite domestic competition structure focused on the 'Superleague' which provides weekly elite competition" (Sport England, 2005, p. 7). The intention to improve the recognition and profile of England Netball as a marketable brand and to enhance the visibility of netball through multi-media platforms was also identified. England Netball targeted the promotion of excellence by an objective to improve senior world ranking from 3 to 2 by 2013. The following section discusses more specifically, the emergence of the NSL in 2005 as part of the strategy for elite performance at England Netball since 2003.

\section{Strategy and Planning at England Netball: Elite Performance and the NSL}

In 2003, Sport England commissioned an independent review of England Netball's world-class performance programme as part of the 1999-2002 funding cycle review and in response to England's showing at the 2003 World Championships. England placed $4^{\text {th }}$ after losing 46-40 to Jamaica. Combined with relatively large win-loss margins to the eventual winners, New Zealand (60-41), and runners-up, Australia (45-37), the performance of the England team was considered an underachievement by England Netball personnel. The independent review illustrates an approach that directed resource capabilities towards a strategy for improving elite performance and national team success. One of the specific findings reported by the independent consulting group was that the nature and extent of the domestic competitions involving England's elite players were inadequate for improving individual and team performances. As part of the strategy formulation for elite performance, the then-Chief Executive of England Netball invited the consultancy team to review the domestic structure of the game in 2004. One of the resulting reforms was the inception of the 
NSL, which built on the previous Super Cup competition; a 2-3 month round-robin and playoff competition consisting of regional teams that took place at the end of the domestic county system in May/June. The major content for the NSL strategy was the development of a franchise-based model with franchises serving as the foundation through which player performance could be enhanced and managed.

The NSL franchise application process was originally designed to encourage applications and secure representation from each of the traditional England Netball regions (East, East Midlands, London and South East, North East, North West, South, South West, West Midlands, Yorkshire) with the exception of London and the South East, the largest of the regions which had the potential to secure more than one franchise. Drawing on our interview material we found that the consultancy company responsible for the review of the domestic structure created a template application and a 9-10 team competition was envisaged. More than one franchise application was received for each region leading to a competitive application process judged by a panel. Members of this panel included representatives of the board of directors of England Netball, the consultancy company, and the founding director of the English Institute of Sport (a network of high performance centres) who had Australian Netball credentials specific to the organisation and structure of netball in Australia (a top ranked netball nation with an established, commercially orientated league; the ANZ League).

Six areas of franchise 'fitness' were assessed; athlete status and careers, court standards, facilities, links with regional/national associations, business model, athlete support for coaching and sport science. The initial applications successful in securing a franchise berth were Brunel Hurricanes, Celtic Dragons, Galleria Mavericks, Leeds Carnegie, Loughborough Lightening, Northern Thunder, Team Bath and Team Northumbria. Since the first competition in 2005 the membership of the NSL has undergone 3 notable changes; the inclusion and of the Scottish franchise, Glasgow Wildcats in 2008/09 and its subsequent 
elimination in 2011/12; the replacement of Brunel Hurricanes by Surrey Storm in 2009/10 and the renaming of two franchises, the Galleria Mavericks to Hertfordshire Mavericks in 2009/2010 and Leeds Carnegie to Yorkshire Jets in 2011/12. To date, the title sponsor has also undergone 3 changes. The inaugural sponsors, Figleaves (a lingerie company), were replaced by The Co-operative in 2006/07, before the incumbent sponsor, FIAT, took over in 2011/12. The dynamic character of the NSL is noted and we expect further significant changes to the franchise membership and format of the competition as it continues to develop. Prior to exploring the empowered franchise framework that characterises the NSL and discussing the relationship between franchising and England Netball's elite performance strategy we provide an overview of franchising in sport and leisure services.

\section{Franchising in Sport}

The term franchising has been used to cover a wide range of business relationships reflecting a growing trend for new commercial systems and opportunities in a range of sectors (Fulop, 2000; Lashley \& Morrison, 2000). Franchising has a history of development from the late $19^{\text {th }}$ century with a significant growth phase evident in the USA during the economic boom of the 1950 s, where franchising systems became widely employed in the hospitality service sector for the management of hotels and restaurants (Fulop, 2000; Taylor, 2000). With the globalization of US-led franchises in hotels (e.g. Holiday Inns), coffee retailing (e.g. Starbucks) and fast food (e.g. McDonalds) franchising has developed as an important business model in the UK service sector. As Fulop (2000) and Lashley and Morrison (2000) explain, the most common method of franchising is the business format franchise characterised by: permission from the franchisor to the franchisee to sell branded goods and services; provision of an established and effective method of operation that includes a system of on-going management support; fee payment by the franchisee to the franchisor; and legal distinction between franchisee and franchisor. 
There is a degree of salience in the business format model and commercial professional sport in the USA and Europe. Sport franchises are most commonly associated with the North American male professional leagues in baseball (MLB), ice hockey (NHL), basketball (NBA) and American football (NFL). The extant literature on sport franchises tends to focus on the economics of these sports (Gratton\& Taylor, 2000; Lavoie, 2000), applying theoretical concepts of the firm, micro-economic principles of business behaviour modelling and various statistical analyses in understanding the market structure of sport (see Scully, 1995) and the organization and management of particular sport businesses (see Quirk \& Fort, 1992; Rosner \& Shropshire, 2011). There is also a field of sociological study concerned with the impact of major sport franchises on cities/regions (see Schimmel et al., 1993).

For Johnson $(1996,1998)$ the acquisition of sport franchises at major and minor levels has become the ubiquitous endeavour of politicians and sports entrepreneurs in the USA and Europe. The highest level and biggest sports operating within a franchise framework are teams privately owned by wealthy individuals or partnerships but can also be part of very large corporations. Furthermore, successful professional sports franchises are hugely profitable ventures. The annual revenue generated by the largest US professional sport, the NFL peaked at $\$ 8.48$ billion in 2010 with an average NFL franchise valued over $\$ 1$ billion (Hambrecht et al, 2011). Such sport businesses operate as monopolies while receiving a host of federal and state tax breaks, make extensive use of playing venues and facilities subsidised by public funds and are managed within a system of profit maximisation obtaining revenue through gate receipts, media funding, stadium revenue (hospitality, advertising and leasing), and licensing fees and merchandising (Branch Jnr, 2008; Eitzen, 2009; Sage \& Eitzen, 2008; Schaffer, 2006; Scherer \& Jackson, 2004). Professional sport franchises, then, reflect more closely the "traditional military structure" of the business format franchising founded upon 
formal mechanistic procedures required for efficiency and controllability (Lashley, 2000, p 96). The next section considers the NSL as an example of an empowered franchise model.

\section{The Empowered Franchise Model in the NSL}

The following discussion draws on evidence generated via 22 semi-structured indepth interviews conducted between 2009 and 2011 with personnel responsible for the organization and management of individual franchises as well as the marketing and public relations of the NSL. It also uses data gathered from documentary analysis of England Netball Whole Sport Plans and annual reviews. Interviews were conducted with personnel defining themselves variously as franchise managers, business managers, and media/marketing managers, and with those involved in sports marketing consultancy, sport sponsorship, sports media-marketing and public relations associated with the game of netball. Pseudonyms have been used to protect the anonymity of the interviewees. Our agenda of questions was based on exploring four broad themes: the aims and objectives of individual franchises and/or the UK NSL; the networks of support and challenges faced in the achievement of the aims and objectives; the organizational structure and management of franchises and the NSL; and the franchisor-franchisee relationships. Our findings show the emergence of an empowered franchise model in the NSL which we discuss next.

NSL franchises reflect some of the broad theoretical principles of franchising. In the first instance, each is bound by contractual responsibilities to the franchisor, title sponsor and media conglomerate responsible for televising the games (SKYSPORTS). There is a franchise agreement; a type of contract explained to us by one sports marketing agent (Tim) as a set of "general regulations relating to the Netball Superleague tournament". This contract sets out the rules by which England Netball expect the NSL to operate and detail the requirements of the franchisees in relation to: establishment of the league; ownership, management and control; NSL objectives, season, notation and competition rules; the League 
Management Committee and its annual meeting with England Netball; commercial agreements, goodwill and intellectual property rights; franchisee benefits; insurance; finance and accounts; renewal and withdrawal; and discipline and liability. The contract also provides a legal distinction between the franchisor and the franchisee which could serve to protect the interests of both parties should it be required. Furthermore, the structure of the NSL provides the opportunity for this network of franchises to operate as an elite sports competition and a comprehensive pathway for performance. Finally, England Netball grant permission to franchises to establish and manage a team that is eligible to play in the NSL, effectively giving permission to sell the Superleague brand; a kind of trademark in Ferrand and McCarthy's (2009) terms. In studies of the structural characteristics of sports organisations three defining dimensions have been identified: specialization, standardization and centralization (Slack \& Hinings, 1987; Kikulis et al, 1989; Theordoraki\& Henry, 1994). We draw on these dimensions in our analysis of the NSL finding that there are varying and overlapping features of each in the resultant empowered franchise framework. The core feature of the NSL franchise system is that it operates within a flexible framework in which success is connected to relatively personal strategies and choices, and/or collaborative partnerships. This is an "empowered franchisee" model (Lashley, 2000, p 92) which represents a shift from the centralized hierarchical model of the business format franchise to one which is decentralized and informal and whereby different franchise are characterised by high degrees of diversity in terms of organization environment and their own structural characteristics of specialization and standardization.

\section{From Centralisation to Decentralisation}

Centralisation refers to the extent of involvement in hierarchical decision making. When one considers that the Board of England Netball took the decision to develop the NSL, create the franchise system and define the contractual details it is possible to argue that the 
system has a centralised chain of command. Individual franchise personnel do not take a core part in England Netball's strategic decision making about elite performance. There is a larger network of scouting and/or nomination for talent identification and access to performance pathways at county, regional and national levels in which players can be selected and deselected at any time. The overall performance strategy in relation to rankings targets for National Teams, selection and management of England squads, Excel Performance Pathways and anti-doping regulations rests with England Netball in what could be described as a "functional hierarchy of authority" (Kikulis et al., 1989, p 134). The NSL franchise system is one aspect of a performance strategy in which England Netball's vision is now to become the number 1 ranked team in the world in the next 10 years (England Netball, 2012).

However, there is evidence of decentralising processes within the franchise framework in which many decisions about the NSL franchises are made at lower levels of the hierarchy by franchise personnel. Apart from deciding which franchises can operate within the NSL and providing an overarching set of contract regulations for the NSL which states that England Netball own the league and retain intellectual property and commercial rights, franchises are relatively free to make decisions about the organisation and structure of their franchises. This means that selection of players, franchised-based commercial activity and administrative decisions lie with franchise management personnel. As one head coach explained "my job here is to get the best players I can to the franchise......we want to create an ethic of training, dedication, performance and success ....the franchise decides how that happens". This is in contrast to other examples of franchise-based sports leagues that have increasingly adopted cartel-like features and are characterised by monopoly power (Stewart et al, 2005).

This aspect of the decentralised nature of the NSL franchise model means that decision-making processes that impact on the on-court performance and off-court 
presentation of league games are spread out to individual franchises located as they are in different regions of the country and in different environments. The flatter hierarchy that has emerged with this type of decentralisation is empowering because it encourages the development of new ideas, products and/or services and allows attention to be paid to customer desires in local situations. As Graham (Franchise Manager) summarised:

We think in terms of customers ...we are selling netball products (anything from a ball adapter to a full netball installation)...and now services (the Superleague game, the camps etc). We have built up a netball community here ..we know what our customers want ... we have our finger on the pulse and know what's coming up in our region netball-wise.

\section{Standardisation and Informalization}

Standardisation and by association, formalization, refers to the extent to which employees are guided by policies and procedures. In short, standardisation concerns the rulebound character of employment behaviour within an organisation. There are certainly standardised and formalised operating mechanisms within the overarching organisational framework of England Netball in relation to elite performance. As already detailed in this paper the development of athletes, coaching and officials are controlled and coordinated via a network of standardised systems, formal procedures and specialized job roles such as talent identification systems, long-term athlete development pathways and planned competition schedules. But we would argue that in addition to the decentralised character of the NSL empowered franchise model the organisational structure in relation to the operation of individual franchises is relatively informal and non-standardised. Most of our interviews took place in the 2008/2009 season; Superleague 4. The NSL was at this time still an immature league. Decentralisation allowed informal, non-standardised processes and structures to emerge within each individual franchise as people found their own ways of doing things and 
patterns of local interactions shaped the franchises. One head coach, Debbie described the personnel running the franchises as having "a pretty free reign" over management processes on and off the court. And Claire (Franchise Manager) explained that:

there's no set systems or processes in place and I had asked from the outset is there any kind of league manual or information plan, communication plan on how this league runs, but the entire league progress has been on emails from day one....what I'm now doing is preparing an event manual and our franchise manual, one will be the franchise operational logistics and one will be the actual day-to-day event manual.

These informal processes of operation are framed by the existence of formal franchise aims. The dominant and central business interest of franchises is player performance and team success. To some extent informalization can make a contribution to the formal strategic elite performance objectives of England Netball because all the franchises have a common and formalised goal to improve the quality of performance. There is potential to nurture the informal processes that have merged in obtaining such goals where it contributes to high levels of motivation within particular franchise management systems. Such high levels of motivation are one way to ensure quality of individual and team performances. For example, the performance sport agenda, encapsulated in the franchise operation, directly connects to financial resourcing, visibility/profile, and more specifically to the adoption and maintenance of systematic, scientific and professional processes in elite athlete development models (Green \& Oakley, 2001). Such elite performance models were described by several of our respondents. For example, Helen (Head Coach) noted that:

The franchise is about ... athlete performance...it is science ....from talent identification to coaching to training to playing ....it has to be planned well from the governing body.... through the franchise ....and all the council and regional 
partners...to my job as head coach ... all of this needs financial support ...so we have to be commercially viable as well.

\section{Specialisation and Diversity}

Specialisation refers to the extent to which job roles and activities are internally variable and the degree to which individual employees are directed towards sets of specifically defined tasks. Like other amateur sports organisations, England Netball operates through a series of specialized professional (paid) and volunteer (unpaid) roles connected to management, administration and coaching. We found also that the precise organization of each netball franchise, the business models, and presentation of games, is also characterised by a high degree of horizontal specialisation reflecting the skills, experiences and values of those managing the franchises and playing in them. Such specialisation has intensified since the inception of the franchises. Simon (Franchise Manager) explained:

I mean in the first couple of years we had a lot more say in it, but now we're regulated a lot more and clamped down, basically because it didn't work. England Netball organised the year and no-one was very organised, it was all franchises ringing each other and sorting stuff out...The first couple of years I was very hands on doing absolutely everything but our departments been restructured so a lot of the PR, marketing, advertising will go to a specific team that's going to be in charge of all those.

Another interviewee (Michael) indicated the development of specialised roles over time illustrating the centrality of the performance goal saying:

My role currently is Performance Sport Manager but before that it was Team Manager so that included everything from performance sport to events to income generation to sponsorship, community engagement. Obviously that portfolio work has really broadened over the last 4 or 5 years and new staff members have come in now to look 
at those areas of community income generation, community events etc, so my role's now been sort of narrowed down, but at the same time it gives us an opportunity to really develop more quality around the performance agenda.

While there appears to be increasing horizontal specialisation, the number of levels of specialisation in the organisation of each franchise, the vertical specialisation is low. Different people have specialised jobs but there is a flat hierarchy of command. There appears to be no single person within the franchises to whom everyone if responsible. For example, Harriet explained: "we all put a bit in to it and we've sort of got our own roles. We didn't say - you're doing this and you're doing that...you're in charge".

The specialised nature of roles and activities within franchises is also shaped by particular aspect of difference and diversity in terms of the overall approach to management. Franchise personnel appeared to be managing towards a range of diverse objectives and targets. For example, in one University-based franchise, a manager (Matt) explained:

We work by the NSL rules ..then we've got our own targets for the franchise...and a whole range of different objectives and projects ....including performance sport but also events, sponsorship, working in the community, and all those different agendas.

A partner in one franchise that was sponsored by a city/regional organisation (Fiona) noted that:

The franchise works for us as a way of promoting the city ..there is a vibrancy in this city around netball ... that was our hook for wanting to be a part of the NSL....developing netball and promoting the city ...as a place for high level netball ....and a place to visit.

For some franchises commercial imperatives overlapped with an ethos of on-court success. This was emphasised by a franchise manager (Graham) who noted that: 
our vision is. ..we work hard at making the money to run the franchise ....we have our objectives ..commercially and for performance ....different to England Netball ....but obviously in the same system because we want to develop the best players and ultimately win.

When we consider the overlapping character of decentralisation, informalization, specialisation and diversity we have found the empowered franchise model in the NSL to be enabling in terms of developing elite performances and increasing the visibility of elite netball across the UK and globally. According to one England Netball report (2007) "Press and other media coverage has trebled year on year" (p 8) and 2006 / 07 saw the first ever full series of 23 televised programmes on SKYSPORTS dedicated to netball. Such media visibility served to produce an impressive "cumulative audience of well over 2.5 million people" (England Netball 2007, p 8). Several of our interviewees emphasised the point made by one head coach that "the Superleague is fantastic for the players ...it's weekly high quality games ...it's instrumental in the development of performance athletes". Since the inception of the NSL, the performance of the English National Team against leading teams has improved. Having failed to medal in the 2002 Commonwealth Games, England obtained bronze medals in the 2006 and 2010 Games. Similarly, they are 'closing the gap' on the top two teams in the world, New Zealand (\#1) and Australia (\#2). After placing $4^{\text {th }}$ in the 2009 World Fastnet Series, losing to Jamaica (22-33) and Australia (18-23); England placed $2^{\text {nd }}$ in the 2010 competition, beating Australia (26-25) in the semi-finals before falling to New Zealand (2628). England's steady improvement culminated in a $1^{\text {st }}$ place finish in the 2011 World Fastnet Series, beating Australia (27-17) in the semi-finals and New Zealand (33-26) in the final.

There is also evidence of a developing culture of player migration with England netball players being employed to play in the professional league in Australia and New Zealand. For example, Sonia Mkoloma (Central Pulse, Canterbury Tactix, New South Wales 
Swifts), Eboni Beckford-Chambers (West Coast Fever), Jade Clark (Waikato/Bay of Plenty Magic, LG Mystics), Tamsin Greenway (Queensland Firebirds), Geva Mentor (Melbourne Vixens), Jo Harten (Canterbury Tactix) and Carla Dziwoki (Queensland Firebirds) have all recently gained ANZ experience while continuing their involvement in the NSL. One head coach explained that such player migration serves to improve the skill and performances of NSL franchise players stating that "some of our girls have been headhunted for the ANZ league. They learn a lot performance-wise, about what it's like to be employed in a professional league. I'm hoping they bring something back to the franchises here about where they can develop on and off the court".

The decentralised, informalized, horizontally specialised yet diverse character of the empowered franchise model of the NSL represents a looser form of partnership arrangement, which can create more effective lines of support for improved consistency, performance and quality (Fulop, 2000).This is the purpose of the League Management Committee. One Sports Marketing Consultant (Tim) explained his role on, and the character of, the committee as "the operational committee of the competition ....an entity that really is the guardian of the rules and regulations in a playing sense of the competition and for which I am strategic advisor if you like. I conduct the end of season league review which involves going round each of the franchises and seeing how they're doing on and off court and drawing conclusions from that which are then fed back in to the strategic development of the competition".

To an extent, the empowered model within which NSL franchises have emerged allows them to be associated with a reputation and named brand whilst having the freedom to operate in a "controlled, assisted and supported environment" (Fulop, 2000, p 27). As described by Lashley (2000), empowered franchises represent a "symbiotic relationship in which both the franchisor and the franchisee are experts" ( $p$ 101). And this point was illustrated by a franchise business manager (Claire) who emphasised that "England Netball 
regulate the league ....SKYSPORTS have their requirements. Our on-court management know about the players. I have more than 10 years experience of business, sports sponsorship, marketing-led contracts and culture and sport....I bring my expertise in business". There is a hands-on approach to the management of franchises and we have witnessed and heard about extremely motivated personnel committed to the development of elite players for franchise and national team success. But there is also a developing business logic defining the operation of franchises. NSL franchises cannot be defined as commercial in the strictest sense of the term. In other words they are not for-profit, nor are they solely concerned with making money (Gammelsaeter, 2010). However, alongside the performance ethos there are commercial influences, which in our view, are characterised by the emergence of netball intrapreneurs. In the following discussion we explore further the way that high levels of motivation and intrepreneurial skill are central to success in the franchising system.

\section{Netball Intrapreneurs}

The groups who have entered into the UK NSL franchise system have done so voluntarily and some of the key personnel involved at franchise level can be thought of, in Morrison's (2000) terms, as intrapreneurs. Intrapreneurs represent a type of "internalized entrepreneurship" sharing many of the characteristics of entrepreneurs in terms of commitment, motivation and creativity; however, they operate within the collective culture of the system (Lashley, 2000, p 71). For some franchising personnel, the looser relationship with the England Netball (the franchisor) provided unique opportunities for intrapreuerial activity. As Sue noted (Media-marketing manager):

This franchise is lucky because I bring all my skills and knowledge from working in media. I am really passionate about this game. And I just think that maybe more commercial people are needed in the game to move it on a bit, but that's happening slowly. And the NGB has to move along with us really. I am always pushing them 
(England Netball) with projects to raise the profile, make it more profitable. I'm always looking for commercial partners/private sponsors. You have to think - what is our identity? How can we market it? What is its value? How can we get exposure?

In Pinchot's (1985) landmark work, the intrapreneur is conceptualised as the "intracorporate entrepreneur" ( $\mathrm{p}$ xii), the internal entrepreneur. The intrapreneur is employed and located within the organisational set up but has the freedom and incentive to construct and develop their own ideas for their own profit. As the previous quote shows, the significance of such a role within the NSL franchises is in the ability to develop innovative practices for the success of one's own ideas as well as that of the broader commercial viability of netball franchises. To an extent, some franchise personnel are "imaginative action takers" who "circumvent or even sabotage the formal systems that supposedly manage innovation" (Pinchot's, 1985, p. xi).Some franchise managers like Harry illustrated the ways it was possible to harness business practices that are new to the UK netball culture in order to engender performance and commercial success:

We wanted to pay the athletes, to bring in the best players and develop a quality competitive team right from the start ... I promised to sell out every game. That's a 1000 per game. Every game....I don't mind saying we paid players a signing on fee about $£ 1000$....My view was that this would work with 4-5 mark players getting $£ 1$ 2000 signing on fees, a quota of match fees, all expenses, business class travel and then all the usual fitness / training / coaching / equipment needs...it's about realising the business potential.

\section{Commercial Potential of the UK Netball Superleague}

The relationship between sport and commerce has a long and complex history and scholarly work in the field is wide ranging. Slack (2004) argues that the strengthening links between sport and commercialisation are one of the most dominant features of modern sport. 
While netball has developed within a framework of amateurism and remains an amateur game at all levels, the elite level is now characterised by desires to embrace, or an inability to avoid, commercial imperatives as a source of revenue (Forster, 2006). This point was explicitly raised by a sports marketing consultant (Tim) who explained that one of the objectives of the NSL was "very much directed to towards increasing the marketing and commercial profile of netball as a whole in terms of attracting sponsors, attracting commercial revenues, raising the profile in media terms". To this end, initial efforts have proved relatively successful, with the NSL securing a title sponsor each season and brokering a deal with SKYSPORTS to provide regular media coverage of the games.

We are specifically concerned in this part of the paper with the character of the commercial potential offered through the empowered franchise system evident in the NSL. We use the term commercialisation here to signal the use of sport to produce an income and we illustrate that franchising represents a commercial operating system related to income generation which is increasingly being harnessed in the NSL. We focus on the evidence of opportunity to harness commercial principles rather than an account of any specific amounts of profitability. Commercialisation of the NSL franchises is supported through the previously mentioned franchise contract regulations that set out specific franchisee benefits in this regard. Specifically, the franchisee benefits are intended to enable commercial activity within individual franchises. Rights to develop and commercially exploit a team name, identity and logo are held by each individual franchise, as are; rights to secure franchise / secondary sponsorships, to acquire local intra-regional broadcast coverage for home matches, to record and exploit the sale of recorded games and to retain ticket sale and merchandising revenues. Some franchise personnel are particularly motivated by the opportunity to make commercial decisions. Pippa (Franchise Media Marketing Manager) whose marketing skills had been 
developed through work in the media explained her ability to capitalise on these franchise benefits saying:

You have to go for the whole market approach to sell the franchise ....getting the players exposure ....on TV, radio, papers ... our website is superb ... our kit looks good ....there are lots of other things like road shows ..to maintain visibility in the market.

Furthermore, Harry (Franchise Manager) was clear about the potential of netball franchises to develop and exploit commercial profits saying:

The netball franchise is a perfect way to sell our brand of sports facility. We know the biggest spenders in leisure/sport are Mums and that there is also a participation challenge in getting and keeping young girls involved in physical activity and sport and so netball seemed the perfect way to make money and encourage activity.

There is a view amongst those managing the franchises that the NSL in the UK could be more commercial. As Harry (Franchise Manager) noted "the game has great potential to be a really good TV sport, develop its commercial focus and range and scope and it can certainly be used in brand marketing if franchises are led well". One consequence of the decentralised, informal and differentiated structure of the empowered franchise framework in netball, then, is the encouragement of innovative and visionary business ideas intended to maximise commercial imperatives.

The empowered franchise framework that we have discussed reflects aspects of the broader rationale for franchising improve 3 commercial aspects of an organisation: (1) market penetration; (2) capital/income generation; (3) commercial viability (Forward \& Fulop, 1996). In terms of market penetration the UK NSL was conceived as a way to promote and develop the elite brand of the game. One marketing consultant [Tim] involved in the initial development of the NSL stated that: 
The objectives for the competition were very much for the development of talent and performance ...but the other side was very much directed towards increasing the marketing and commercial profile of the sport as a whole in terms of visibility....sponsors, commercial revenues, media visibility terms and in general awareness terms.

In terms of the first commercial aspect of franchising, (market penetration) the importance of penetrating the sports market with a competitive female team sport was also highlighted by public relations executives working for England Netball in 2008/09. Beth, for example noted that:

Through the Superleague we want to raise the profile of the sport. When people actually go to the super league games, men especially, they're quite impressed by how fast and physical it is and I guess... they wouldn't expect to see the netball that they see at super league.

Several franchise managers echoed the idea that the NSL was a structure that would enable the game to develop into a more high profile women's sport that would then have the potential to grow in the commercial market of sport. Graham (Franchise Manager) for example explained that the franchise was "a business for us ....we've finished in the black which is a big bonus...there is commercial potential....I do consider myself a businessman here"

For some of the personnel responsible for the franchises in our study, the business of netball is linked to specifically to the second and third commercial dimensions of franchising, capital generation and commercial viability. Harry (Franchise Manager) made this point clear by saying "I wanted to do this right - in a business sense. This was all about selling our brand ...pay the athletes ...sell out games". 
Some franchises were more focused and effective in establishing themselves as profitable. The commercial potential of these franchises were described by one sports marketing consultant as:

Absolutely top notch....because there is nothing within those franchises that they don't know the price of or the value of, and they sell it (netball) very effectively to the extent that they are probably the franchises that make a profit year in and year out because they run on very commercial lines.

Potential forms of income generation come variously from ticket sales, merchandising, and the provision of netball coaching services at day events or weekly coaching schools. The precise level of income generation varies between the franchises. Several franchises commonly ran at a loss, but a strong theme from our interviews was connected to developing strategies to enhance the commercial viability of the franchises over time. One of the University franchise managers (Simon) explained that "we have massive potential to pull in more money ...through ticket sales.. if we get home fixtures at times when all the students are in the University ....and through community work ...you know coaching camps".

The use of franchising in the UK NSL cannot be directly connected to what can be read in the literature as a $4^{\text {th }}$ dimension of the commercial framework of franchising, 'improving performance in areas of marginal profitability' because the starting point for the franchise structure was never one that had a singular commercial foundation. Profitability was never the raison d'être of the NSL. The commercial potential of the League was aligned with the elite performance strategy and was viewed by key personnel as a character of the game that could develop with the maturation of the League. As one expert in sport sponsorship (Sarah) noted "the League is still immature ....people have to give the game time to develop commercially ...and it terms of its media profile ..it's got massive potential". 
Netball remains an amateur sport, principally organised and funded within the system of NGB management in UK Sport. Yet, we argue that the objective to improve the quality and consistency of the elite game through the NSL was certainly rooted in a long-term vision for the game to develop along commercial lines. Commercial influences have entered the game more strongly with the inception of the NSL. This brings an additional logic to the culture of netball in the UK such that there is a synthesis of commercial, intrapreneurial and performance interests (O’Brien \& Slack, 2004). This might be usefully defined as a pluralist franchise logic (see Gammelsaeter, 2010).

\section{The NSL Empowered Franchise Model: The Need to Manage Strategic Change in Elite}

\section{Performance}

We would not wish to suggest that all franchises employ commercially driven intrapreneurs or are characterised by commercial and on-court performance success. Nor are we claiming that the franchisee relationships with England Netball are inherently or necessarily harmonious. In such a dynamic environment where change is being driven by a network of political, economic and social forces, netball management personnel are being continually challenged with leading and adapting to change. While positive business arrangements characterise some of the franchisor-franchisee relationships, there can be challenges for both parties. We provide examples of the tensions within the NSL franchise system that have been revealed in our research. We argue that such issues should be addressed by relevant personnel within the franchises and at England Netball if the League is to be a sustainable one that can continue to enhance elite performance, attract players to the game from grass roots, and fulfil its commercial potential. Following McGraw et al. (2012) there appears to be no waning in the scale and scope of change in sports organizations and managers need to have considerable expertise in understanding and coping with such change. 
There is evidence from our interviews that demands connected to cost, time and labour can be underestimated by franchisors. The average season cost of running a franchise between 2008-2010 was approximately $£ 50-80,000$ [approx. $€ 58,000$ - $€ 77,000 / \$ 92,800$ $\$ 123,200]$.Franchises are supported financially within the Superleague by whoever is taking 'ownership' of the management of the team be that in a University, as part of a City / Regional organisation or National Governing Body or through a range of commercially orientated financial support mechanisms. On the issue of costs many of our respondents supported the claim that "running any franchise is a cost ...how it's paid for varies...and so does how much profit if any can be made" (Marie, Head Coach). It was also the case that the decentralised, informal, differentiated structure can lead to feelings of a lack of support in a system that is still new:

I think that support from England Netball could be more ...it's all still new ....they could be more helpful ....it all takes so much work in the franchises ...and we are selling netball for England Netball ....as well as the franchise...they could help more somehow (Simon, Franchise Manager).

Where tensions arise, the franchisee needs an effective forum for raising on-going concerns about the quality of continued support from the franchisor, the rigorousness of the business concepts and the capability of other franchisees in the network. Pippa (Media Marketing Manager,) noted, for example:

It's everybody's responsibility to ensure the Superleague is a sustainable commercial product. That doesn't mean England netball are just making that happen, the franchises make it happen too. It's got to come from the top (the NGB). OK there is some support but in the franchises there isn't the (business) knowledge out there yet. I'm working to help England Netball now. They appreciate that the Superleague as a product needs to change. It needs to be marketed better, there needs to be more 
consistency across franchises. You can't just have one franchise with a good product, business, media profile, team of players. Consistency has to happen now.

The problems of a decentralised, informal and diverse franchise structure are, then, connected to inconsistent management practices and a dependence on individual intrapreneurs for strong leadership. Freedom to manage does not always create a consistent product particularly in relation to match day experiences. For example, our interviews found that while franchises are required to provide the visiting team with post match hospitality such as hot food on Franchise Business Manager (Claire) noted "well we provide 2 pasta dishes and rice...you know...of nutritional value to these elite players and you go somewhere else and you get a slice of pizza". The creation of a netball spectacle on match days is also variable with some franchises providing a pre-match, interval and post match entertainment of a higher quality than others. For example,Heather (Media-marketing manager) compared their game day experience to those at other franchises by saying:

I go on the mic here, do the Mexican wave, have a drum going and get crowds shouting. We raffle a signed team shirt or ball and all the kids get excited and want to win. We have a prize for the best cheerers. It really is good. Then we go to other places and it's just so flat. They are very well funded so they don't even actively sell any tickets. Some away games are poor, they don't bother - they don't have to.

Furthermore, in terms of on the court performance, in a system that does not draft the best players nationally to different franchises but allows individual franchises to attract players, Graham (Franchise Manager), like others we spoke with noted "we can't have a league always dominated by one team with all the England players ..something has to be done about that...it's not good for the fans ...it's not good for sustainability of the league". Superleague players are attracted to particular franchises for a variety of reasons including location, coaching staff, other players, the possibility of University bursaries, expenses payments, 
signing fees and win bonus payments. This has certainly created an uneven playing field and an unbalanced competition with one or two teams consistently reaching the finals year on year. Since its inception, the competition has been dominated by TeamBath (winners in 2005/06, 2006/07, 2008/09, 2009/10) and Hertfordshire Mavericks (2007/08, 2010/11).If, as some research has shown, fans prefer games and leagues that have an uncertain outcome and where no single team dominates then there will need to strategies for the NSL franchises to create a more balanced competition (Quirk \&Fort, 1992). Such an approach, though is contrary to the decentralised, informalizedand diverse character of the empowered franchise model and shifts the organisational logic of the NSL to more of a "master-servant" relationship characteristic of leagues that exhibit monopoly power processes (Stewart, Nicholson \&Dickson, 2005).

Fulop (2000) surmises, "a franchise is a partnership, albeit an unequal one, and it has been the difficulties of coping with the complexities of this arrangement, and the potential for conflict that may ensue, that has led to the failure of some franchised operations" (p 29). This point was bought into sharp relief during the course of our research with the dissolution of the Brunel Hurricanes in the 2008-09 season and the inception of Surrey Storm in the 2009-10 season. Discussions with personnel from both these franchises revealed that Brunel University had sponsored the Hurricanes since the inception of the Superleague, bankrolling the cost of the team (approximately $£ 60-80,000$ per season) and providing training facilities and sport science services. However, in 2009, in the context of the wider economic pressures facing Universities, Brunel University was no longer willing to commit total financial support to the franchise. The then media-marketing manager of the Brunel Hurricanes (Pippa) explained that:

Brunel University have given us fantastic support over the years. We know they like being associated with a Superleague team for the media profile and the great public 
relations they get from it. But it's a lot of money and they cannot commit it all....only about half. It's not enough for a franchise to operate. We need to explore all our other options.

While the tensions here are not directly between the franchisee (Brunel Hurricanes) and the Franchisor (England Netball) they do illustrate potential problems in the complex partnership arrangements resulting from the decentralized, informal and diverse organization that characterises the empowered franchise model. As Forward and Fulop (1996) indicate, operating a business within a network of franchised and managed relationships is often difficult because the decentralized organisation that is so central to the franchising concept is juxtaposed to the centralized management of already established corporate groups. Although Forward and Fulop's (1996) discussion is connected to big-business corporations, such tensions between franchisor and franchisee, as we have shown, are evident in the NSL system. Still, problems in franchise relationships can also engender renewal in any franchise system.

As a result of the problems experienced in the Brunel Hurricanes franchise a new franchise emerged in 2010; Surrey Storm. Supported by the CEO of a major sport park facility the rationale for the franchise was threefold; "to make money and sell our sport brand, to develop women's elite sport and to encourage female participation in netball" (Harry, Franchise Manager). Thus, the renewal process in this example favoured the commercial franchise, something illustrated in the most recent award of franchise status to teams for the 2012 season, all of which have stronger commercial partnership arrangements than previous franchises. Indeed, the 2012 NSL incorporated changed franchise line-up, a new title sponsor (FIAT) and the final was contested by Northern Thunder and Surrey Storm, two franchises that have employed a more commercial approach to operations, perhaps indicating a more coherent synthesis of commercial and performance objectives. 


\section{Conclusion}

As the UK NSL enters its $8^{\text {th }}$ year of operation, it is maturing in terms of its franchisebased organisation and structure. Changes to the League membership and format continue to focus on developing elite performance and success of the England team. There are also strengthening commercial imperatives within the franchise structure. The empowered franchise framework of the NSL is a decentralised organisational model characterised by different levels of standardisation and specialisation across the franchises. An empowered franchise model may produce inconsistent management practices and a dependence on individual intrapreneurs for strong leadership, but for netball in the UK the NSL franchise system is enhancing performance of elite players and improving the results of the England team in international competition.

One key concern can be raised in relation to our analysis of the NSL in this paper. As the performance strategy framing the NSL was implemented there were additional radical changes to the overall structure of grass roots participation and competition with the former inter-county competition being dissolved to make way for an expanded club based national system (The Premier League), the inception of the National Talent League (regionally and franchise-based teams for talented 14-19 year olds), as well as the inclusion of the national schools competition. Arguably such strategies were formulated with little direct engagement with the views of the wide England Netball membership. Such strategic change is best described as a radical turnaround managed by directive command. It remains to be seen what impact such changes have had on participation in netball across the UK. This leads us to emphasise that there is an emerging research agenda around Netball in the UK which are connected to the four broad themes: management of performance of netball; management of human resources in netball; marketing of netball and economics of the game.

\section{Acknowledgements}


The authors would like to thank two anonymous reviewers for the constructive feedback which have shaped the arguments in this paper. The research was supported by the Centre for Sport, Physical Education and Activity Research (SPEAR) at Canterbury Christ Church University.

\section{References}

Amis, J., Slack, T. \& Hinings, C. (2004). 'Strategic change and the role of interests, power and organizational capacity', Journal of Sport Management, 18, 158-198.

Birkbeck Sport Business Centre (2010). Good Governance in Sport: A Survey of UK National Governing Bodies of Sport. University of London.

Branch Jr., D. (2008). The Charlotte Bobcats: (re) launching a new (old) NBA franchise. Sport Marketing Quarterly, 17(1), 57-62.

Dutton. T. (2009). Statement from Richard Lewis in response to the report by Timothy Dutton QC into the World Class Payments Bureau. Retrieved from:http://www.sportengland.org/about_us/our_news/statement_from_richard_lewis. aspx. Retrieved on 26th November 2011.

Eitzen, S.D. (2009). Fair and Foul: Beyond the Myths and Paradoxes of Sport (4 ${ }^{\text {th }}$ edition). Maryland: Rowman\& Littlefield Publishers, Inc

England Netball. (2005) Our Great Game: Whole Sport Plan 2005-2009. Hertfordshire: England Netball.

England Netball. (2006). All England Netball Association Limited Annual Report 2005-2006. Hertfordshire: England Netball

England Netball. (2007). All England Netball Association Limited Annual Report 2006-2007. Hertfordshire: England Netball

England Netball. (2008).All England Netball Association Limited Annual Report 2007-2008. Hertfordshire: England Netball 
England Netball. (2012).10-1-1 Conference Outcome.Retrieved from http://www.englandnetball.co.uk/about-england-netball/10_1_1_conference_outcome Retrieved on 28th May 2012.

Ferkins, L., Shibury, D. \& McDonald, G. (2005) The role of the board in building strategic capability: Towards an integrated model of sport governance research. Sport Management Review. 8 (1), 195-225

Ferrand, A. \& McCarthy, S. (2009). Marketing the Sports Organisation: Building Networks and Relationships. London: Routledge.

Forster, J. (2006). Global sports organisations and their governance. Corporate Governance. $6(1), 72-83$.

Forward, J. \& Fulop, C. (1996). Large established firms entry into franchising: An exploratory investigation of strategic and operational issues. International Review of Retail, Distribution and Consumer Research ,6 (1), 34-52.

Fulop, C. (2000). History and Development. In Lashley, C \& Morrison, A. (Eds.) Franchising Hospitality Services. Oxford: Butterwork Heinemann, 22-36.

Gammelsaeter, H. (2010). Institutional pluralism and governance in "commercialized" sport clubs, European Sport Management Quarterly, 10, 5, 569-594.

Gratton, P. \& Taylor, I. (2000). Economics of Sport and Recreation. London: Routledge.

Green, M. \& Oakley, B. (2001). Elite sport development systems and playing to win: Uniformity and diversity in international approaches, Leisure Studies, 20(4), 247-67.

Grix, J. (2009). The impact of UK sport policy on the governance of athletics.International Journal of Sport Policy, 1 (1), 31-49.

Hambrecht, W., Hambrecht, E., Morrissey, P. \& Taylor, A. (2011). The U.S Professional Sports Market \& Franchise Value Report 2011. San Francisco: Hambrecht \& Co. Sports Finance Group. 
Harrison, P. (2010). Good Governance in Sport. Paper presented at Good Governance in Sport Conference. Birkbeck Sport Business Centre, University of London. Friday $16^{\text {th }}$ April 2010.

Henry, I. \& Lee, P. C. (2004). Governance and Ethics in Sport. In J. Beech \& S. Chadwick (eds.). The Business of Sport Management. London: Prentice-Hall, pp 25-42.

Hoye, R., Smith, A., Nicholson, M., Stewart, B. and Westerbeek, H. (2008).Sport Management: Principles and Applications. London: Elsevier.

International Federation of Netball Associations (INFA). (2011). About INFA. Retrieved from http://www.netball.org/ifna.aspx. Retrieved on November $20^{\text {th }} 2011$.

International Federation of Netball Associations (INFA). (2012). Current World Rankings. Retrieved from http://www.netball.org/ifna.aspx?id=94. Retrieved on June $13^{\text {th }} 2012$.

Johnson, T. (1996). Assessing the value of sports facilities: the importance of non-economic factors. Economic Development Quarterly, 10 (4), 369-381.

Johnson, T. (1998). Minor league baseball: risk and potential benefits for communities large and small. Review of Policy Research, 15 (1), 45-55.

Kikulis, L., Slack, T, Hinings, B. \& Zimmerman, A. (1989). A structural taxonomy of amateur sport organizations. Journal of Sport Management, 3, 129-150.

Lashley, C. (2000). Empowered franchisees? In Lashley.C \& Morrison, A. (Eds.) Franchising Hospitality Services. Oxford: Butterwork Heinemann, p 92-113

Lashley, C. \& Morrison, A. (Eds.) (2000). Franchising Hospitality Services.Oxford: Butterwork Heinemann.

Lavoie, M. (2000). Economics and sport. In Coakley, J \& Dunning, E. (eds.) The Handbook of Sports Studies. London: Sage, p 157-170

McDonald, I. (2005). Theorising Partnerships: Governance, Communicative Action and Sport Policy. Journal of Social Policy, 34 (4) 579-600 
McGraw, P., Taylor, T. \& Lock, D. (2012). 'Theoretical approaches and practical strategies for change management', in L. Robinson, P. Chelladurai, Bodet, G. and Downward, P. Routledge Handbook of Sport Management. London: Routledge. pp.116-134.

Minikin, B. (2012). The planned development of sport organizations, in L. Robinson, P. Chelladurai, G. Bodet and P. Downward. Routledge Handbook of Sport Management. London: Routledge. pp. 42-57.

Morrison, A. (2000). Entrepreneurs or intrapreneurs? In Lashley.C \& Morrison, A. (Eds.) Franchising Hospitality Services. Oxford: Butterwork Heinemann, p 68-91.

Mowbray, D. (2012). 'The contingent and standards governance framework for national governing bodies', in L. Robinson, P. Chelladurai, G. Bodet and P. Downward. Routledge Handbook of Sport Management. London: Routledge. pp. 26-41.

Nicholson, M. \& Hoye, R. (2008) 'Delivering strategic change in complex sport environments: Country Racing Victoria', International Journal of Sport Management and Marketing, 4, 1, pp. 18-32

O’Brien, D. \& Slack, T. (2004). Strategic responses to institutional pressures for commercialisation: a case study of an English Rugby Union Club, in T. Slack (eds.) The Commericalisation of Sport, London: Routledge. pp. 164-185.

Pinchot, G. (1985). Intraprenuering. New York and London: Harper Row.

Quirk, J \& Fort, R. (1992). Pay Dirt: The Business of Professional Team Sports. New Jersey: Princeton University Press.

Roser, S. \& Shropshire, K. (Eds.) (2011). The Business of Sports. London: Jones and Bartlett.

Sage, G. \& Eitzen, S. (2008). Sociology of North American Sport ( $8^{\text {th }}$ Ed). Paradigm Publishers 
Schaffer, R. (2006). A piece of the rock (or the rockets): The viability of widespread public offerings of professional sports franchises.Virginia Sports \& Entertainment Law Journal, 5(2), 201-232.

Scherer, J. \& Jackson, S. J. (2004). From corporate welfare to national interest: Newspaper analysis of the public subsidization of NHL hockey debate in Canada.Sociology of Sport Journal, 21(1), 36-60.

Schimmel, K. Ingham, A. \& Howell, J. (1993). Professional team sport and the American city: urban politics and franchise relocation. In Ingham, A. \& Loy, J. Sport in Social Development: Traditions, Transitions, and Transformations. Champaign. Ill: Human Kinetics Press. pp. 211-44.

Scully, G. (1995). The Market Structure of Sports.Chicago: University of Chicago Press.

Slack, T. (Ed). (2004). The Commercialisation of Sport. London: Routledge.

Slack, T. \& Hinings, B. (1987). Planning and organizational change: A conceptual framework for the analysis of amateur sport organizations. Canadian Journal of Sport Sciences, 12, 185-193.

Sport England. (2004). The framework for sport in England: Making England an active and successful sport nation a vision for 2020. Retrieved from http://www.sportengland.org/facilities__planning/planning_tools_and_guidance/plann ing_contributions/national_framework_for_sport.aspx. Retrieved on $26^{\text {th }}$ May 2012.

Sport England. (2008). Sport England Strategy 2008-2011. Retrieved from http://www.sportengland.org/search.aspx?query=Strategy+2008-2011. Retrieved on $26^{\text {th }}$ May 2012.

Stewart, B., Nicholson, M., \& Dickson, G. (2005). The Australian Foootball League's recent progress: a study of cartel conduct and monopoly power, Sport Management Review, 8, 96-117. 
Tagg, B. (2008). Imagine, A Man Playing Netball! Masculinities and Sport in New Zealand. International Review for the Sociology of Sport.43 (4), 409-430.

Taylor, S. (2000). Hotels. In Lashley.C \& Morrison, A.(2000). (Eds.) Franchising Hospitality Services. Oxford: Butterwork Heinemann. pp. 170-191.

Theodoraki, E \& Henry, I. (1994). Organisation structures and contexts in British National Governing Bodies of sport, International Review for the Sociology of Sport, 29 (3), 243-265. 